\title{
Effects of exposure to low concentrations of chlorinated hydrocarbons on the kidney and liver of industrial workers
}

\author{
P J Boogaard, P S J Rocchi, N J van Sittert
}

\begin{abstract}
An assessment has been made of biochemical alterations in renal and hepatic functions of 73 male operators employed for an average of $8 \cdot 2$ years (range $0.5-23$ years) in a chemical plant producing chlorinated hydrocarbons. Exposure to allyl chloride (AC), 1,3-dichloropropene (DCP), epichlorohydrin (ECH), and hexachlorocyclopentadiene (HEX) has regularly been determined by personal air monitoring since 1980. Although exposures to DCP and ECH were well below currently accepted maximum allowable concentrations (MACs), relatively high exposures to $A C$ and HEX, occasionally exceeding the MAC, have been measured. The results of the kidney and liver function tests were compared with those of a control group comprising 35 men employed at the materials division and not occupationally exposed to chemicals. Biochemical alterations of liver function were assessed by determination in serum of alanine and aspartate aminotransferases (ALAT, ASAT), alkaline phosphatase (AP), total bilirubin (BIL), $\gamma$-glutamyltranspeptidase (GGT), lactate dehydrogenase (LDH), and total bile acids (SBA). No differences between the exposed group and the control group were found. Nor were differences found in biochemical tests for renal tubular damage (urinary alanine aminopeptidase (AAP) and N-acetyl- $\beta$-D-glucosaminidase (NAG)) and renal tubular function (urinary retinol binding protein (RBP).

Total urinary protein and albumin excretion were measured to assess the integrity of the
\end{abstract}

Shell Internationale Petroleum Maatschappij BV, Health, Safety, and Environment Division, Biomedical Services, PO Box 162, 2501 AN, The Hague, The Netherlands

PJ Boogaard, N J van Sittert

Shell Nederland Raffinaderij/Chemie B v, Occupational Health, Hygiene and Biomedical Services, PO Box 7000, 3000 HA Rotterdam, The Netherlands

P S J Rocchi, N J van Sittert glomerulus. Urinary total protein did not differ between the groups, but urinary albumin, although within normal limits in both groups, was significantly higher $(p<0.02)$ in the exposed group. This difference in urinary albumin could not simply be explained by exposure to chlorinated hydrocarbons because albumin concentrations did not correlate with the duration of employment. It is concluded that long term exposure to concentrations of AC, DCP, ECH, or HEX below or near the current limit threshold value does not lead to clinically significant effects on kidney and liver.

\section{(British Fournal of Industrial Medicine 1993;50:331-339)}

The organochlorine plant of Shell Pernis produces several chlorinated hydrocarbons, including allyl chloride (AC), epichlorohydrin $(\mathrm{ECH}), 1,3-$ dichloropropene (DCP, a mixture of roughly equal amounts of the $\mathrm{Z}$ - and E-isomers), and hexachlorocyclopentadiene (HEX). In general chlorinated hydrocarbons are considered to be potential hepato- and nephrotoxicants in humans. ${ }^{12}$ This assumption is based on extensive evaluations of the toxicity of these compounds in laboratory animals, in which they all produce nephro- and hepatotoxicity on acute oral exposure, although chronic exposure to their vapours seems less harmful. ${ }^{3-11}$ The acute nephrotoxicity of chlorinated hydrocarbons can be expected from metabolic activation via the mercapturic acid pathway. ${ }^{12}$ Also various mechanisms of bioactivation of chlorinated hydrocarbons that could eventually lead to hepatotoxicity have been described. ${ }^{13}$

The limited data available on the noxious effects in humans relate mainly to case studies of acute intoxication. ${ }^{14-17}$ Recently, two cases of biochemical alterations that may indicate early renal effects were reported for acute exposure to DCP. ${ }^{18-19}$ Hardly any information is available, however, on the possible adverse health effects on the kidney and liver of chronic exposure to low concentrations of chlorinated hydrocarbons. The operators in the Shell plant are potentially exposed to mixtures of these 
chlorinated hydrocarbons, which may have additive or even synergistic toxic effects.

Alterations in biochemical indices for renal or hepatic function may be an early warning of alterations in these organs that ultimately lead to loss of functional integrity. In this study some sensitive biochemical tests for the detection of early changes in liver and kidney have been conducted in conjunction with standard periodic occupational health assessment. Personal air monitoring has been regularly performed at this plant since 1980 . Exposure levels have only been measured, however, with few operators and therefore the results of the renal and liver tests cannot be correlated with individual exposures for the investigation of any dose-response relation. As a surrogate for individual exposures, therefore, duration of employment of each operator was chosen.

\section{Methods and materials}

POPULATION AND STUDY DESIGN

The study group comprised 73 men working in five shift duty at the organochlorine plant. The control group consisted of 35 men, all of them employed at the materials division on day duty, and not occupationally exposed to chemicals. The subjects participated in a voluntary periodic occupational health assessment held in March and April 1990. Information was obtained on occupational history, demographic characteristics, and lifestyle by means of a self administered questionnaire. All questionnaires were reviewed for accuracy and completeness by the medical officer of the plant. Subjects with a known history of non-occupational nephropathies or urinary tract diseases were excluded from the study as were subjects with a systemic disease with possible renal sequelae (for example, diabetes mellitus).

Blood and urine were collected from all participants between 800 and $1000 \mathrm{am}$. Subjects had not been asked to fast. Tests for the detection of renal tubular injury were measurements of the urinary enzymes alanine aminopeptidase (AAP) and $\mathrm{N}$ acetyl- $\beta$-D-glucosaminidase (NAG). Urinary retinol binding protein (RBP) was determined as an index of impaired proximal tubular function and urinary albumin and total protein was determined to study the integrity of the glomerulus. Possible effects on the liver were studied by the determination of serum alanine aminotransferase (ALAT), alkaline phosphatase (AP), aspartate aminotransferase (ASAT), total bilirubin (BIL), $\gamma$-glutamyltranspeptidase (GGT), lactate dehydrogenase $(\mathrm{LDH})$, and total serum bile acids (SBA).

\section{EXPOSURE TO CHLORINATED HYDROCARBONS}

Until 1987 the operators in the organochlorine plant did not produce or handle HEX, which was manufactured in a unit of an insecticide plant as a starting chemical for manufacture of dieldrin. After dieldrin production stopped, the HEX unit was, for organisational convenience, added to the organochlorine plant and a joint rotatory work schedule for the operators of the HEX unit and the organochlorine plant was implemented. Personal air monitoring with personal air sampling pumps and solid sorbent tubes was introduced about 1980 to determine air concentrations of AC, ECH, DCP, and HEX in the breathing zone. Monitoring campaigns included measurements both during normal operation of the plants and during specific activities with a higher potential of exposure such as maintenance. The sampling and subsequent analyses were performed according to validated methods by the Shell Pernis Laboratory. Before 1985, the measurements did not cover the full duration of the working shift, but were carried out over periods of about five hours. Since 1985 only full shift monitoring has been performed and results have been reported as eight hour time weighted average (TWA) air concentrations. To facilitate comparison it was assumed that the results obtained before 1985 reflect eight hour TWA exposure to the chlorinated hydrocarbons. The data for eight hour TWA exposure were fitted to a $\log$ normal distribution from which the geometric mean (GM), geometric standard deviation (GSD), and arithmetic mean (AM) were calculated with the program HYGIENIST (Netherlands Society of Occupational Hygiene, 1990). The same program was used to calculate the $95 \%$ upper confidence interval (P95) and the compliance probability $(\alpha$ (\%)).

\section{ANALYTICAL METHODS}

Urine samples were collected in polyethene containers. Specific gravity and $\mathrm{pH}$ were determined immediately after sampling and each sample was split into fractions and stored in polystyrene tubes at $-20^{\circ} \mathrm{C}$ until analysis. The $\mathrm{pH}$ of the samples ranged from 4.8 to 7.8 for operators in the organochlorine plant and from $5 \cdot 0$ to $7 \cdot 3$ for subjects in the materials division. No losses of enzyme activities or protein concentrations occurred when urine was stored under these conditions. The samples for AAP analysis were preserved with ethylene glycol $(30 \% \mathrm{v} / \mathrm{v})$ before freezing. ${ }^{20}$ NAG was determined on a Cobas Mira autoanalyser with a commercial reagent kit (Cortecs Diagnostics, Deeside, Clwyd, UK) according to Yuen et al. ${ }^{21}$ Total protein was determined by the Biuret method after precipitation with Tsuchiya's reagent; AAP was determined manually according to Mattenheimer et al. ${ }^{20}$ Thirty one of the 108 urine samples had a $\mathrm{pH}<5.5$ (two were below $\mathrm{pH} 5 \cdot 0$ ). Because $\beta_{2}$-microglobulin $\left(\beta_{2} M\right)$ might have degraded at this $\mathrm{pH} \quad \beta_{2} M$ 
analyses were not carried out and RBP was determined instead. For the determination of RBP and albumin the frozen urine samples were transported on ice to Professor R R Lauwerys' laboratory at the Department of Occupational Medicine and Hygiene of the Catholic University of Louvain, Brussels, Belgium where the measurements were carried out within one week with latex agglutination inhibition immunoassays. ${ }^{22} 23$

Each variable of renal function was determined on the same day to avoid day to day analytical variations. All urinary variables were normalised for urinary creatinine concentration determined on a Cobas Mira autoanalyser by the Jaffé method. For the determination of liver enzymes and BIL in serum, $10 \mathrm{ml}$ blood samples were collected. Tests were carried out within six hours after collection on a Hitachi 705 autoanalyser with standard clinical chemical techniques; SBA was determined as total $3 a$-hydroxy bile acids with an Enzabile reagent kit (Nycomed, Oslo, Norway). The test was carried out in only 56 workers of the study group $(77 \%)$ and in 29 of the controls ( $83 \%$ ) because 23 samples of frozen serum were randomly lost due to clerical error.

\section{STATISTICS}

Statistical analyses were performed with the aid of the mainframe version of the SAS statistical software package (version 5.18), with $\alpha<0.05$ as the level of significance. Each variable was tested for normality with the Kolmogorov-Smirnov test. Neither function variables for the kidney nor those for the liver showed a normal distribution, either before or after logarithmic transformation. After a logarithmic transformation the variables, with the exception of $\mathrm{LDH}$, fitted much better to a Gaussian distribution. Therefore, the difference in the means between the distributions found for both the study and the control groups was compared by Wilcoxon's rank sum test.

The distributions of possible confounders in both groups were compared using the $\chi^{2}$ test for discrete variables (smoking, drinking, sporting habits, and medication) and the Wilcoxon's rank sum test for continuous variables (age, height, weight, and body mass index). The kidney and liver function variables (except for LDH values), were modelled after logarithmic transformation and the influence of working in the organochlorine plant on renal and hepatic function was assessed by $F$ test with linear regression analysis. Finally, a likelihood ratio $\chi^{2}$ test was used to compare the frequencies of outliers (defined as values that exceeded the upper limit of the $95 \%$ confidence interval $(95 \% \mathrm{CI})$ as determined in control populations) in both groups.
Table 1 Characteristics of the study and the control group

\begin{tabular}{lccl}
\hline & $\begin{array}{l}\text { Study } \\
\text { group }\end{array}$ & $\begin{array}{l}\text { Control } \\
\text { group }\end{array}$ & p Value \\
\hline Number of volunteers & 73 & 35 & - \\
Mean age (y) & $36 \cdot 4$ & $42 \cdot 3$ & 0.007 \\
Mean height (cm) & 179 & 179 & 0.942 \\
Mean weight (kg) & $81 \cdot 3$ & $81 \cdot 5$ & 0.803 \\
Body mass index & $25 \cdot 1$ & $25 \cdot 2$ & 0.633 \\
Number of smokers & $19(26 \%)$ & $13(37 \%)$ & $0 \cdot 140$ \\
$\begin{array}{l}\text { Smoking habits } \\
\text { (cigarettes/day) }\end{array}$ & $4 \cdot 0$ & $6 \cdot 0$ & $0 \cdot 197$ \\
$\begin{array}{l}\text { Number of alcohol users } \\
\text { Alcohol consumption }\end{array}$ & $65(89 \%)$ & $28(80 \%)$ & 0.204 \\
$\quad$ (glasses/week) & 12.2 & 10.8 & 0.669 \\
$\begin{array}{l}\text { Number playing regular sport } \\
\text { Number of medication users }\end{array}$ & $29(40 \%)$ & $17(49 \%)$ & 0.384 \\
& $9(12 \%)$ & $5(14 \%)$ & 0.777 \\
\hline
\end{tabular}

\section{Results}

POPULATIONS

The periodic occupational health assessment is voluntary. It was attended by all 36 workers from the materials division (control group), but one person was excluded from the study because the urine sample was too small for all the tests. For the operators of the organochlorine plant (study group), 73 out of 86 (response rate $85 \%$ ) underwent the medical examination. These operators had been working at the plant for 0.5 to 23 (mean 8.2) years. Table 1 summarises the characterisics of the study group and the control group. The groups matched well for all variables except age. Wherever appropriate, the test results were analysed after correction for age.

\section{ASSESSMENT OF EXPOSURE}

Figure 1 shows the means of the airborne concentrations of AC, DCP, ECH and HEX measured from 1980 to 1991 . Tables $2-5$ summarise the corresponding $95 \% \mathrm{CIs}, \mathrm{P} 95$, and $\alpha$ values. The mean (AM) exposure concentrations to DCP and $\mathrm{ECH}$ were well below the current occupational exposure standards ( 5 and $4 \mathrm{mg} / \mathrm{m}^{3}$ respectively) and it was concluded from the values for $a$ that exposures above these concentrations were highly unlikely. By contrast, exposures to AC and HEX were sometimes high and occasionally even exceeded the MAC of 3 and $0.11 \mathrm{mg} / \mathrm{m}^{2}$, respectively. Although mean exposure values have decreased over the years, relatively high exposures to AC and HEX may still occur during maintenance and shut down activities.

\section{MODEL AND CONFOUNDERS}

The control group did not completely match the study group for age; therefore its possible confounding influence was evaluated. It seemed that age or $(\text { age })^{2}$ was a statistically significant confounder in this study for ASAT, AP, GGT, and 

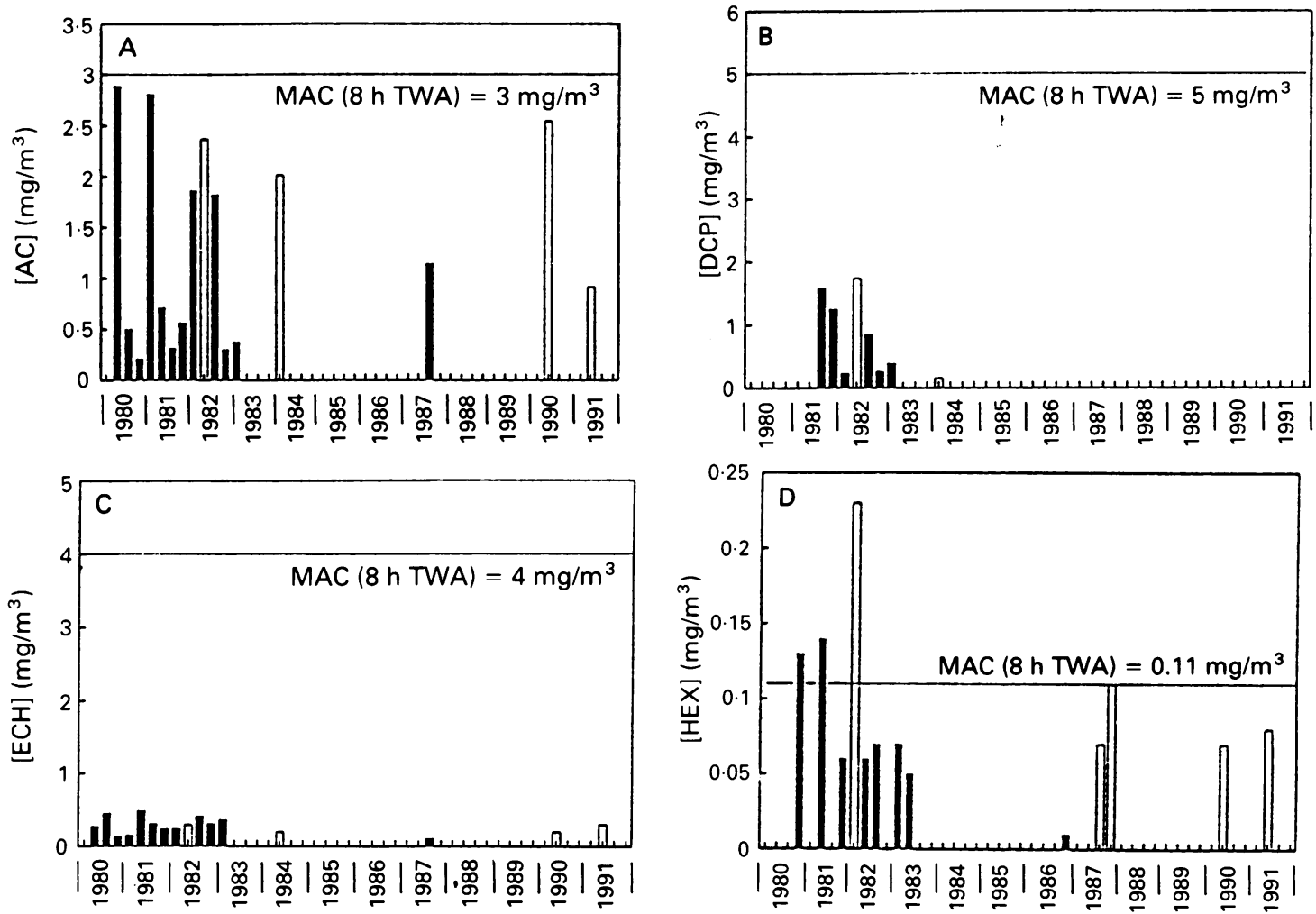

Figure $1 \mathrm{~A}-\mathrm{D}$ Mean airborne concentrations ( $8 \mathrm{~h} T \mathrm{TWA}$ ) of allyl chloride $(A), 1,3$-dichloropropene (B), epichlorohydrin (C), and hexachlorocyclopentadiene (D) measured by personal air monitoring from 1980 to 1991 . The solid bars represent the results during normal operation and the open bars during maintenance stops. The horizontal lines indicate the current MAC value for each of the compounds measured.

Table 2 Personal air sampling: allyl chloride $\left(\mathrm{mg} / \mathrm{m}^{3} ; M A C=3 \mathrm{mg} / \mathrm{m}^{3}\right)$

\begin{tabular}{|c|c|c|c|c|c|c|c|c|c|c|}
\hline \multicolumn{2}{|c|}{ Period } & \multirow{2}{*}{$\frac{N o}{11}$} & \multirow{2}{*}{$\frac{n}{56}$} & \multirow{2}{*}{$\begin{array}{l}G M \\
1 \cdot 91\end{array}$} & \multirow{2}{*}{$\frac{G S D}{2 \cdot 51}$} & \multirow{2}{*}{$\frac{A M}{2 \cdot 89}$} & \multirow{2}{*}{$\frac{(95 \% C I)}{(2 \cdot 25-3 \cdot 70)}$} & \multirow{2}{*}{$\frac{P 95}{8 \cdot 68}$} & \multirow{2}{*}{$\frac{x(\%)}{31 \cdot 2}$} & \multirow{2}{*}{$\begin{array}{l}\text { Plant status } \\
\text { Normal operation }\end{array}$} \\
\hline May & 1980 & & & & & & & & & \\
\hline Aug & 1980 & 13 & 45 & $0 \cdot 25$ & $3 \cdot 32$ & 0.50 & $(0.35-0.72)$ & $1 \cdot 80$ & 1.92 & Normal operation \\
\hline Oct & 1980 & 6 & 88 & $0 \cdot 11$ & $3 \cdot 13$ & $0 \cdot 21$ & $(0 \cdot 16-0 \cdot 27)$ & 0.72 & 0.19 & Normal operation \\
\hline Feb & 1981 & 5 & 14 & $2 \cdot 11$ & $2 \cdot 21$ & $2 \cdot 81$ & $(1 \cdot 75-4 \cdot 52)$ & $7 \cdot 78$ & 32.9 & Normal operation \\
\hline Jun & 1981 & 7 & 20 & 0.56 & $2 \cdot 04$ & 0.71 & $(0 \cdot 50-1 \cdot 00)$ & $1 \cdot 81$ & 0.93 & Normal operation \\
\hline Sep & 1981 & 9 & 28 & $0 \cdot 23$ & $2 \cdot 17$ & 0.31 & $(0.23-0.42)$ & 0.82 & 0.05 & Normal operation \\
\hline Dec & 1981 & 5 & 19 & $0 \cdot 16$ & $5 \cdot 31$ & 0.56 & $(0 \cdot 24-1 \cdot 27)$ & $2 \cdot 49$ & 3.96 & Normal operation \\
\hline Mar & 1982 & 8 & 32 & 0.99 & $3 \cdot 16$ & $1 \cdot 86$ & $(1 \cdot 22-2 \cdot 83)$ & 6.57 & $16 \cdot 8$ & Normal operation \\
\hline Jan & 1982 & - & 15 & $1 \cdot 24$ & $3 \cdot 32$ & $2 \cdot 37$ & $(1 \cdot 19-4 \cdot 71)$ & 8.93 & $23 \cdot 1$ & Maintenance \\
\hline Sep & 1982 & 7 & 20 & 0.77 & 3.94 & $1 \cdot 82$ & $(0.94-3.51)$ & $7 \cdot 35$ & $16 \cdot 1$ & Normal operation \\
\hline Dec & 1982 & 5 & 14 & $0 \cdot 29$ & $1 \cdot 24$ & 0.30 & $(0 \cdot 26-0 \cdot 34)$ & 0.41 & $<0.01$ & Normal operation \\
\hline Mar & 1983 & 18 & 18 & $0 \cdot 28$ & $2 \cdot 13$ & 0.37 & $(0.25-0.54)$ & 0.97 & 0.09 & Normal operation \\
\hline Mar & 1984 & 14 & 14 & $0 \cdot 81$ & $4 \cdot 22$ & $2 \cdot 01$ & $(0 \cdot 85-4 \cdot 76)$ & 8.65 & $18 \cdot 2$ & Maintenance \\
\hline Aug & 1987 & 44 & 44 & 0.37 & $4 \cdot 66$ & $1 \cdot 14$ & $(0 \cdot 71-1 \cdot 84)$ & $4 \cdot 65$ & 8.69 & Normal operation \\
\hline Apr & 1990 & 2 & 8 & $2 \cdot 04$ & $2 \cdot 05$ & $2 \cdot 54$ & $(1 \cdot 34-4 \cdot 81)$ & 6.62 & $29 \cdot 4$ & Shut down \\
\hline Apr & $1991^{\star}$ & 11 & 45 & 0.46 & $3 \cdot 27$ & 0.91 & $(0.63-1.30)$ & $3 \cdot 24$ & $5 \cdot 72$ & Shut down \\
\hline
\end{tabular}

No $=$ numbers of workers monitored; $\mathrm{n}=$ number of air measurements; GM (GSD) $=$ geometric mean and standard deviation (log normal distribution); $\mathrm{AM}=$ arithmetic mean; $95 \% \mathrm{CI}=95 \%$ confidence interval of $\mathrm{AM} ; \boldsymbol{x}=$ compliance probability (probability that MAC value will be exceeded).

* Respiratory protective devices were worn; values reflect breathing zone air concentrations. 
Table 3 Personal air sampling: 1,3-dichloropropene ( $\left.\mathrm{mg} / \mathrm{m}^{3} ; M A C=5 \mathrm{mg} / \mathrm{m}^{3}\right)$

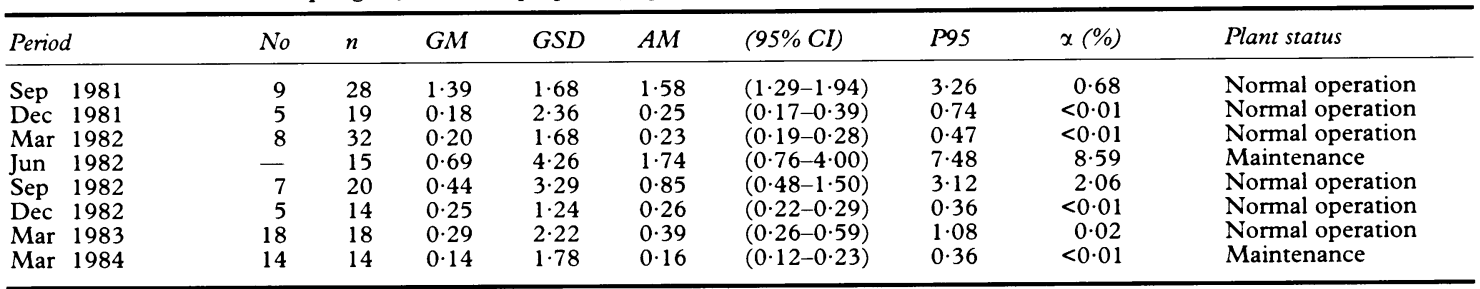

For explanations see table 2 .

BIL. The test results were evaluated with and without correction for age.

\section{BIOCHEMICAL TESTS}

Table 6 summarises the results of the liver tests. No statistically significant differences were found between the study group and the control group for any of the tests (irrespective of whether a correction for age was made or not).

Table 7 summarises results of the renal tests. Mean and median urinary albumin were significantly higher in the study group than in the control group. It seemed that the overall distribution of urinary albumin was shifted to slightly higher values (fig 2). None of the other renal variables showed a significant difference between the study group and the control group.

No significant correlation was found between the amount of urinary albumin and duration of employment at the organochlorine plant $(\mathrm{p}=$ $0.529)$. Nor was a significant correlation found for any of the other renal or hepatic tests. To study the possible effects of long term exposure on kidney and liver the calculations and statistical analysis of

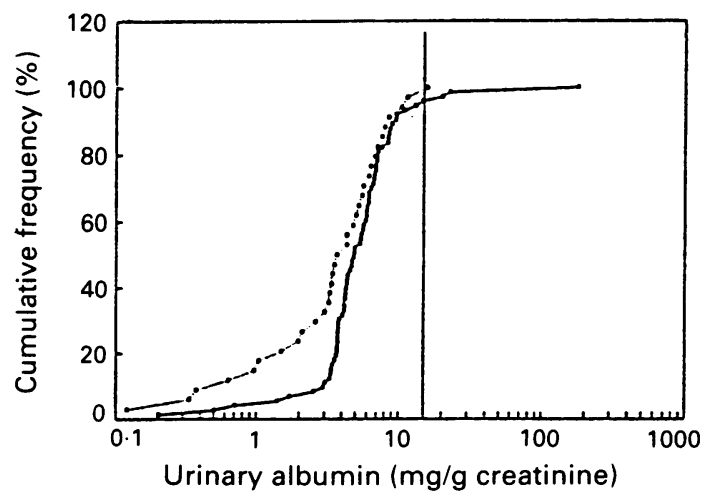

Figure 2 Cumulative frequency distribution of albumin in urine of control group (dotted line) and exposed workers (solid line). The vertical line indicates the maximum "normal" value (upper limit of the $95 \% C I$ ). The distributions are significantly different $(p=0.020)$ even if the operators only employed after 1987 are left out $(p=0.026)$. all the results have been repeated without those for the 12 operators $(16 \%)$ that had been employed only after the merger (data not shown). Again, a statistically significant difference was found only for urinary albumin $(p=0.026)$. This difference was not correlated with duration of employment in the organochlorine plant or HEX unit before the merger ( $p=0.296$ and 0.852 respectively). The overall distribution of urinary albumin in operators employed at the organochlorine plant before the merger did not differ from that of former employees of the HEX unit (fig 3).

\section{Discussion}

As shown in table 1 , the study group and the control group were well matched for all life style and demographic factors except age. The frequency of outliers of the values of the routine serum and urinary variables in the exposed group was not significantly different from that in either the present control group or control groups from other studies performed in our laboratory (tables 6 and 7).

The results of the personal air monitoring indicated that exposures to DCP and ECH were well

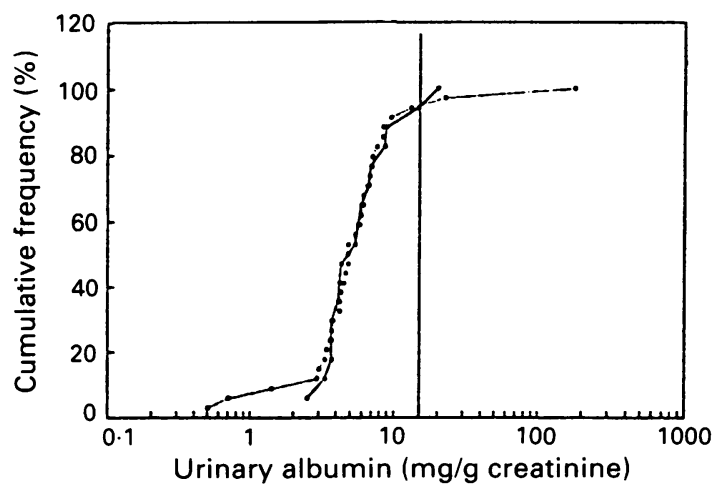

Figure 3 Cumulative frequency distribution of albumin in urine of operators who worked in the former HEX unit (dotted line) or the organochlorine plant (solid line) before the merger in 1987. The vertical line indices the maximum "normal" value (upper limit of the $95 \%$ CI) The distributions are not significantly different ( $p=0.566)$. 
Table 4 Personal air sampling: epichlorohydrin $\left(\mathrm{mg} / \mathrm{m}^{3} ; M A C=4 \mathrm{mg} / \mathrm{m}^{3}\right)$

\begin{tabular}{|c|c|c|c|c|c|c|c|c|c|c|}
\hline \multicolumn{2}{|l|}{ Period } & \multirow{2}{*}{$\frac{N o}{11}$} & \multirow{2}{*}{$\frac{n}{56}$} & \multirow{2}{*}{$\frac{G M}{0.17}$} & \multirow{2}{*}{$\frac{G S D}{2 \cdot 68}$} & \multirow{2}{*}{$\frac{A M}{0.27}$} & \multirow{2}{*}{$\frac{(95 \% C I)}{(0.21-0.36)}$} & \multirow{2}{*}{$\frac{P 95}{0.86}$} & \multirow{2}{*}{$\frac{x(\%)}{0.07}$} & \multirow{2}{*}{$\begin{array}{l}\text { Plant status } \\
\text { Normal operation }\end{array}$} \\
\hline May & 1980 & & & & & & & & & \\
\hline Aug & 1980 & 13 & 45 & 0.09 & 6.33 & 0.45 & $(0.26-0.79)$ & $1 \cdot 87$ & 1.99 & Normal operation \\
\hline Feb & 1981 & 5 & 14 & 0.13 & $1 \cdot 82$ & 0.15 & $(0.11-0.22)$ & 0.35 & $<0.01$ & Normal operation \\
\hline Jun & 1981 & 7 & 20 & 0.36 & $2 \cdot 23$ & 0.49 & $(0.33-0.72)$ & $1 \cdot 35$ & 0.13 & Normal operation \\
\hline Sep & 1981 & 9 & 28 & 0.22 & $2 \cdot 35$ & 0.31 & $(0.22-0.44)$ & 0.90 & 0.03 & Normal operation \\
\hline Dec & 1981 & 5 & 19 & $0 \cdot 14$ & $2 \cdot 92$ & $0 \cdot 24$ & $(0.14-0.40)$ & 0.82 & 0.09 & Normal operation \\
\hline Jun & 1982 & - & 15 & $0 \cdot 20$ & 2.43 & 0.29 & $(0.17-0.48)$ & 0.86 & 0.04 & Maintenance \\
\hline Sep & 1982 & 7 & 20 & $0 \cdot 29$ & $2 \cdot 36$ & 0.41 & $(0.27-0.62)$ & $1 \cdot 19$ & $0 \cdot 11$ & Normal operation \\
\hline Dec & 1982 & 5 & 14 & 0.30 & $1 \cdot 27$ & 0.31 & $(0.27-0.36)$ & 0.44 & $<0.01$ & Normal operation \\
\hline Mar & 1983 & 18 & 18 & 0.31 & $1 \cdot 73$ & 0.36 & $(0.27-0.47)$ & 0.76 & $<0.01$ & Normal operation \\
\hline Mar & 1984 & 14 & 14 & $0 \cdot 15$ & $2 \cdot 27$ & 0.20 & $(0.12-0.33)$ & 0.58 & $<0.01$ & Normal operation \\
\hline Aug & 1987 & 44 & 44 & 0.07 & $2 \cdot 50$ & 0.11 & $(0.08-0.14)$ & 0.32 & $<0.01$ & Normal operation \\
\hline Apr & 1990 & 2 & 8 & $0 \cdot 18$ & $1 \cdot 62$ & 0.20 & $(0.13-0.31)$ & 0.40 & $<0.01$ & Shut down \\
\hline Apr & $1991^{\star}$ & 3 & 3 & $0 \cdot 27$ & $1 \cdot 70$ & 0.30 & $(0.06-1.49)$ & 0.65 & $<0.01$ & Shut down \\
\hline
\end{tabular}

For explanations see table 2 .

below the current occupational exposure standards. By contrast, exposures to AC and HEX were relatively high and occasionally exceeded the MAC values. Unfortunately, no individual exposure levels were available for all subjects because personal air sampling was applied only to few operators. Consequently, it was impossible to relate dose and effects on a personal basis and the duration of employment was chosen as a surrogate index for exposure.

The serum biochemistry gave no indications of any liver damage in the exposed group compared with the control group. SBA was added to the battery of liver tests routinely carried out during periodic health assessment. Bile acids undergo enterohepatic cycling and as they are efficiently extracted by a healthy hepatocyte, the concentration of SBAs has been proposed as a sensitive marker for early changes in the liver function not associated with cytotoxicity. In a number of studies SBA is claimed to be a more sensitive indicator of early hepatotoxicity in workers exposed to various (chlorinated) hydrocarbons than the routinely assessed parameters (recently reviewed by Franco ${ }^{24}$ ).
In the present study, however, SBA was not significantly higher in the study group than in the control group and its sensitivity was no greater than any of the other liver function variables ( $p>0.05$, McNemar's test). Moreover, it seems that the determination of SBA does not necessarily provide extra information because statistical analysis showed a significant correlation of SBA with determination of GGT ( $p=0.012$, likelihood $\chi^{2}$. It should be noted that SBA has been determined in non-fasting subjects and that in such groups higher SBA concentrations are obtained in comparison with fasting subjects. Whether or not the SBA test would be more sensitive for detecting alterations in liver function in a fasting population (not feasable in industrial workers) remains to be established.

Urinary AAP, NAG; and RBP were used to assess proximal tubular injury (AAP, NAG) or function (RBP): AAP is a proximal tubular brush border enzyme that is excreted into the urine in larger amounts after exposure to tubulotoxic chemicals, ${ }^{25-27}$ and NAG is a proximal tubular lysosomal enzyme that is highly resistant to degradation in urine. NAG was included as a marker for tubular injury, but it may be increased in the case of

Table 5 Personal air sampling: hexachlorocyclopentadiene $\left(\mathrm{mg} / \mathrm{m}^{3} ; M A C=0.11 \mathrm{mg} / \mathrm{m}^{3}\right)$

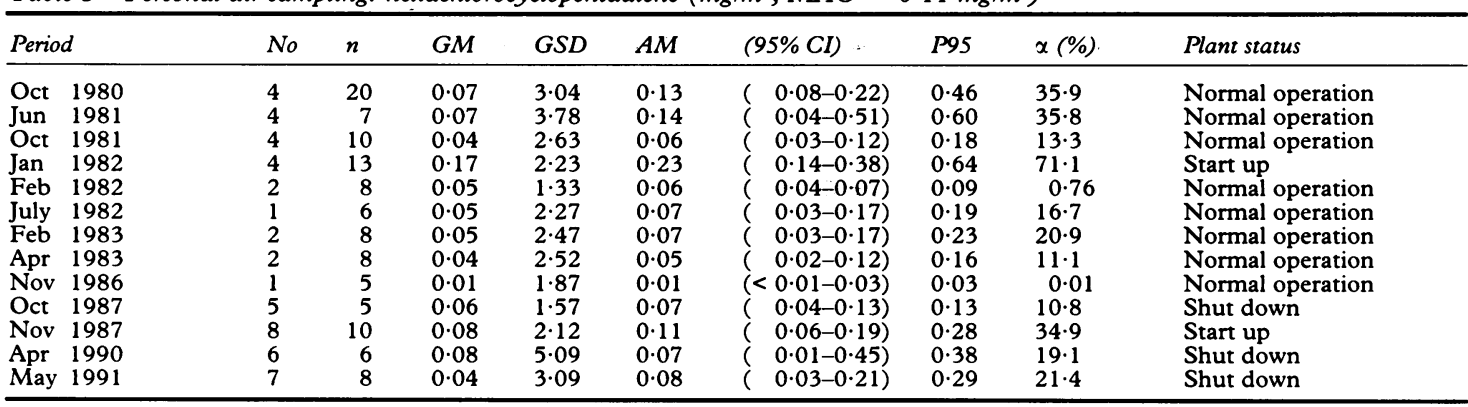

For explanations see table 2 . 
Table 6 Results of the liver function tests in the exposed and control groups

\begin{tabular}{|c|c|c|c|c|c|c|}
\hline \multirow{2}{*}{$\begin{array}{l}\text { Variable } \\
\text { (units) }\end{array}$} & \multicolumn{2}{|l|}{ Mean (median) } & \multicolumn{2}{|l|}{ Range (\% outliers) * } & \multirow{2}{*}{$\begin{array}{l}\text { Upper } \\
\text { normal } \\
\text { valuet }\end{array}$} & \multirow[b]{2}{*}{ Pvalue } \\
\hline & Exposed & Control & Exposed & Control & & \\
\hline $\begin{array}{l}\text { ALAT (U/l) } \\
\text { AP (U/l) } \\
\text { ASAT (U/l) } \\
\text { BIL }(\mu M) \\
\text { GGT (U/l) } \\
\text { LDH (U/l) } \\
\text { SBA }(\mu M)\end{array}$ & $\begin{array}{c}19 \cdot 0(16.0) \\
61.5(58.0) \\
17.3(17.0) \\
12 \cdot 7(11.0) \\
18 \cdot 6(15.0) \\
208(208) \\
6.23(4.45)\end{array}$ & $\begin{array}{c}18 \cdot 1(17.0) \\
56 \cdot 2(53.0) \\
15.8(15.0) \\
11.3(11.0) \\
20.5(16.0) \\
199(195) \\
5.48(3.41)\end{array}$ & $\begin{array}{c}8-57(0) \\
33-114(2 \cdot 7) \\
12-34(1 \cdot 4) \\
5-36(4 \cdot 1) \\
6-63(0) \\
100-320(5 \cdot 5) \\
2 \cdot 4-18 \cdot 2(5 \cdot 4)\end{array}$ & $\begin{array}{c}9-50(2 \cdot 9) \\
33-108(2 \cdot 9) \\
10-26(0) \\
4-19(5 \cdot 7) \\
9-59(0) \\
141-259(0) \\
1 \cdot 3-12 \cdot 7(3 \cdot 4)\end{array}$ & $\begin{array}{l}35-72 \ddagger \\
97 \cdot 109\rfloor \\
26-32 \ddagger \\
17-219 \\
46-73 \ddagger \\
269 \\
12\end{array}$ & $\begin{array}{l}0.717 \\
0.311 \\
0.113 \\
0.337 \\
0.437 \\
0.178 \\
0.140\end{array}$ \\
\hline
\end{tabular}

*No statistically significant difference (likelihood $\chi^{2}$ test) was found between the numbers of outliers in each group; tdefined as the upper limit of $95 \% \mathrm{CI}$ as determined in control groups in our laboratory; ¥dependent on body mass index; fdependent on age;

dependent on smoking habits.

glomerular dysfunction as well. ${ }^{26}$ 28-30 Retinal binding protein, like $\beta_{2} \mathrm{M}$, is a low molecular weight protein that is freely filtered from the plasma in the glomeruli and subsequently reabsorbed by the proximal tubules. This tubular reabsorption is virtually complete. As a consequence, even slight damage to the proximal tubule that results in a decreased pinocytotic activity leads to a substantial increase in urinary excretion of low molecular weight proteins including RBP. ${ }^{31-33}$ Retinal binding protein shows a good correlation with $\beta_{2} \mathrm{M}^{23}$ and has been analysed in this study because of its greater stability in acidic urine. There were no statistically significant differences in AAP, NAG, or RBP between operators from the study group and the control group.

The glomerular integrity was screened by assessment of total protein and albumin. High molecular weight proteins are selectively retained in the glomerulus, which means that their appearance in the urine often reflects an increase in glomerular permeability, although high molecular weight proteinuria may also result from reduced tubular reabsorption. ${ }^{34}$ The determination of a non-renal protein such as albumin is more selective than total protein, as total protein is a summation of low and high molecular weight proteins, which may originate both from serum and from the tubular part of the nephron. Albumin excretion has proved to be a very sensitive parameter to detect early renal changes. ${ }^{27} 34$ The slightly increased urinary albumin concentrations found in this study in the exposed group may be indicative of early changes in glomerular permeability. Only in three subjects of the exposed group, however, $(4 \cdot 1 \%)$ was microalbuminuria (a raised level of urinary albumin not detectable by dipstick methods) found compared with one subject in the control group (2.9\%). This difference was not statistically significant. A tubular origin is highly improbable as a concomitant increase in RBP has not been found ${ }^{26} 34$ and neither NAG nor AAP were increased.

A number of old case studies suggest the potential hepato- and nephrotoxicity to humans of the chlorinated hydrocarbons produced in organochlorine plants. A severe cirrhosis that persisted for more than two years has been described in a worker who accidentally inhaled a high concentration of $\mathrm{ECH}$ for short period. ${ }^{15}$ More recently, workers in a waste water treatment plant were accidentally exposed to HEX concentrations ranging from less than $0.05 \mathrm{ppm}$ to $20 \mathrm{ppm}$ for short intervals (several seconds to 15 minutes); 18 workers out of 97 showed abnormal values in liver tests but abnormalities in values for kidney tests were not found. ${ }^{16}$

Recently, "subclinical alterations" in renal biochemistry were reported after exposure to DCP. Osterloh et $\mathrm{al}^{18}$ reported increased NAG activities in four out of 15 workers at DCP air exposure

Table 7 Results of the renal function tests in the exposed and control groups

\begin{tabular}{|c|c|c|c|c|c|c|}
\hline \multirow{2}{*}{$\begin{array}{l}\text { Variable } \\
\text { (units) }\end{array}$} & \multicolumn{2}{|l|}{ Mean (median) } & \multicolumn{2}{|c|}{ Range (\% outliers)* } & \multirow{2}{*}{$\begin{array}{l}\text { Upper } \\
\text { normal } \\
\text { valuet }\end{array}$} & \multirow[b]{2}{*}{ Pvalue } \\
\hline & Exposed & Control & Exposed & Control & & \\
\hline $\begin{array}{l}\text { AAP }(\mathrm{U} / \mathrm{g}) \\
\text { Albumin }(\mathrm{mg} / \mathrm{g}) \\
\text { NAG }(\mathrm{U} / \mathrm{g}) \\
\text { RBP }(\mu \mathrm{g} / \mathrm{g}) \\
\text { Total protein }(\mathrm{mg} / \mathrm{g})\end{array}$ & $\begin{array}{l}2.78(2.38) \\
8.09(4.76) \\
1.37(1.15) \\
75.8(65.7) \\
42.4(39.9)\end{array}$ & $\begin{array}{c}2.85(2.38) \\
4.68(3.62) \\
1.42(1.06) \\
76.3(63.9) \\
58.2(38.6)\end{array}$ & $\begin{array}{c}1 \cdot 1-9 \cdot 4(1 \cdot 4) \\
0 \cdot 2-178(4 \cdot 1) \\
0 \cdot 3-5 \cdot 5(2 \cdot 7) \\
5-361(5 \cdot 5) \\
12-232(1 \cdot 4)\end{array}$ & $\begin{array}{l}1 \cdot 1-8 \cdot 2(2 \cdot 9) \\
0 \cdot 1-16(2 \cdot 9) \\
0 \cdot 1-4 \cdot 2(8 \cdot 6) \\
4-233(8 \cdot 6) \\
8-255(5 \cdot 7)\end{array}$ & $\begin{array}{c}6 \cdot 9 \\
15 \\
3 \cdot 0 \\
150 \\
200\end{array}$ & $\begin{array}{l}0 \cdot 780 \\
0 \cdot 020 \\
0 \cdot 169 \\
0 \cdot 647 \\
0 \cdot 260\end{array}$ \\
\hline
\end{tabular}

$\star$ No statistically significant difference (likelihood $\chi^{2}$ test) was found between the numbers of outliers in each group; †defined as the upper limit of $95 \% \mathrm{CI}$ as determined in control groups in our laboratory for AAP, NAG, and total protein; for albumin and RBP the values as determined by Lauwerys and coworkers were adopted. ${ }^{22} 23$ 
products greater than $700 \mathrm{mg} / \mathrm{min} / \mathrm{m}^{3}$ (for example, exposure to the threshold limit value for more than two hours). Another study was concerned with kidney and liver tests of a group of 14 soil fumigators who applied DCP. After the season small but statistically significant increases relative to the median values before the season were found in urinary albumin and RBP. ${ }^{19}$ Nevertheless, the median for all liver and kidney tests including albumin and RBP were within the normal range and the differences may also be explained by intraindividual variation. ${ }^{35}$ Moreover, the determinations were carried out on urine collected immediately after exposure so that the minor changes found might be transient, acute effects. In our study no clinically significant abnormalities were found either, but urinary albumin showed a statistically significant increase compared with the control group. Viau et $a l^{\beta 6}$ have reported strikingly similar findings in a refinery population exposed to hydrocarbon solvents-namely, no differences in $\beta_{2} M, R B P$, or NAG but a statistically significant rise, albeit within the normal range, in albumin excretion in refinery employees as compared with a matched control group with clerical or administrative functions. Like these authors, we were unable to relate this small increase in urinary albumin to the duration of exposure. Although the operators who worked in the organochlorine plant before 1987 had a potential exposure to AC, DCP, and $\mathrm{ECH}$, whereas the operators of the former HEX unit were potentially exposed to HEX, no differences were found between these subgroups. Nor was a correlation found between any of the variables measured and the duration of employment in the organochlorine plant and the former HEX unit. Although a possible role of exposure to low concentrations of chlorinated hydrocarbons in the induction of renal disturbances cannot be ruled out at this stage, our findings suggest that factors other than exposure to chlorinated hydrocarbons may be responsible for the effect on albumin excretion. The difference may possibly be caused by the heavier physical workload of the operators under examination compared with the control group or the fact that they work on a shift system whereas the control group works only during the day. Investigations on this point are in progress.

We are indebted to Dr D Lugtenburg (Department of Epidemiology and Biostatistics, Erasmus University, Rotterdam, The Netherlands) for statistical advice. The medical supervision of this study and the critical reading of the manuscript by $M E J$ Caubo (Occupational Physician, Occupational Health Services, Shell Nederland Raffinaderij/ Chemie BV) are also gratefully acknowledged.
Requests for reprints to: Dr N J van Sittert, Shell Internationale Petroleum Maatschappij BV, Health, Safety, and Environment Division, Biomedical Services, PO Box 162, 2501 AN, The Hague, The Netherlands.

1 Torkelson TR, Rowe VK. Halogenated aliphatic hydrocarbons containing chlorine, bromine and iodine. In: Clayton GD, Clayton FE, eds. Patty's industrial hygiene and toxicology 2nd edition, volume IIb. New York: Wiley, 1985:3433-601.

2 Lauwerys R, Bernard A, Viau C, Buchet J-P. Kidney disorders and hematoxicity from organic solvent exposure. Scand $\mathcal{f}$ Work Environ Health 1985;11:83-90.

3 Lu B, Dong S, Yu A, Xian Y, Geng T, Chui T. Studies on the toxicity of allyl chloride. Ecotoxicol Environ Safety 1982;6: 19-27.

4 Pallade S, Dorobantu $M$, Gabrielescu E. Insuffisance rénale aiguë dans l'intoxication par l'épichlorohydrine. Archives des Maladies Professionelles 1968;29:679-88.

5 Quast JF, Henck JW, Postma BJ, Schütz DJ, McKenna MJ. Epichlorohydrin - subchronic studies I. A 90-day inhalation study in laboratory rodents (Fischer 344 rats, Sprague-Dawley rats and $B 6 C 3 F 1$ mice). Dow Chemical, 1979.

6 Yang RSH, Huff JE, Boorman GA, Haseman JK, Kornreich $\mathrm{M}$, Stookey JL. Chronic toxicology and carcinogenesis studies of Telone II by gavage in Fischer 344 rats and $\mathrm{B} 6 \mathrm{C} 3 \mathrm{Fl}$ mice. $\mathcal{F}$ Toxicol Environ Health 1986;18:377-92.

7 Torkelson TR, Oyen F. The toxicity of 1,3-dichloropropene as determined by repeated exposure of laboratory animals. $\mathrm{Am}$ Ind Hyg Assoc f 1977;38:217-23.

8 Parker CM, Coate WB, Voelker RW. Subchronic inhalation toxicity of 1,3-dichloropropene/1,2-dichloropropane (D-D) in mice and rats. F Toxicol Environ Health 1982;9:899-910.

9 Stott WT, Young JT, Calhoun LL, Battjes JE. Subchronic toxicity of inhaled technical grade 1,3-dichloropropene in rats and mice. Fundam Appl Toxicol 1988;11:207-20.

10 Abdo KM, Montgomery CA, Kluwe WM, Farnell DR, Prejean JD. Toxicity of hexachlorocyclopentadiene: subchronic (13-week) administration by gavage to F344 rats and B6C3Fl mice. 7 Appl Toxicol 1984;4:75-81.

11 Rand GM, Nees PO, Calo CJ, Alexander DJ, Clark GC. Effects of inhalation exposure to hexachlorocyclopentadiene on rats and monkeys. $f$ Toxicol Environ Health 1982;9:743-60.

12 Nagelkerke JF, Boogaard PJ. Nephrotoxicity of haloalkyl cysteine-S-conjugates. Life Sci 1991;49:1769-76.

13 Cohen G. Metabolic basis of target organ toxicity. In: Caldwell J, Jakoby WB, eds. Biological basis of detoxication. London: Academic Press, 1983:325-47.

14 David NJ, Wolman R, Milne FJ, Van Niekerk I. Acute renal failure due to trichloroethylene poisoning. $\mathrm{Br} \mathrm{F}$ Ind Med 1989;46:347-9.

15 Schultz C. Fettleber und chronisch-asthmoide Bronchitis nach Inhalation eines Farbenlösungsmittels (Epichlorhydrin). Disch Med Wochenschr 1964;89:1342-4.

16 Kominsky JR, Wisseman CL, Morse DL. Hexachlorocyclopentadiene contamination of a municipal wastewater treatment plant. Am Ind Hyg Assoc F 1980;41:552-6.

17 US Department of Health, Education and Welfare. Criteria document for an occupational exposure standard for allyl chloride. Washington; 1976 NIOSH (NIOSH report 76-204.)

18 Osterloh JD, Wang R, Schneider F, Maddy K. Biological monitoring of dichloropropene: air concentrations, urinary metabolite, and renal enzyme excretion. Arch Environ Health $1989 ; 44: 207-13$.

19 Brouwer EJ, Evelo CTA, Verplanke AJW, Van Welie RTH, De Wolff FA. Biological effect monitoring of occupational exposure to 1,3-dichloropropene: effects on liver and renal function and on glutathione conugation. $\mathrm{Br} \mathrm{F}$ Ind $\mathrm{Med}$ 1991;48:167-72.

20 Mattenheimer H, Frölke W, Grötsch H, Maruhn D, Simane Z. Recommendation for the measurement of "alanine aminopepdase" in urine. $f$ Clin Chem Clin Biochem 1988; 26:635-4.

21 Yuen CT, Kind PRN, Price RG, Prail PFG, Richardson AC. Cholorimetric assay for $N$-acetyl- $\beta$-D-glucosaminidase (NAG) in pathological urine using the $\omega$-nitrostyryl substrate: the development of a kit and the comparison of man- 
ual procedure with the automated fluorimetric method. Ann Clin Biochem 1984;21:295-300.

22 Bernard AM, Lauwerys RR. Latex immunoassay of urinary albumin. F Clin Chem Clin Biochem 1983;21:25-30.

23 Bernard AM, Vyskocil AA, Mahieu P, Lauwerys RR. Assessment of urinary retinol-binding protein as an index of proximal tubular injury.Clin Chem 1987;33:775-9.

24 Franco $G$. New perspectives in biomonitoring liver function by means of serum bile acids: experimental and hypothetical biochemical basis. Br f Ind Med 1991;48:557-61.

25 Price RG, Halman J, Yuen CT. Urinary enzymes as early indicators of renal changes. In: Foa V, Emmett EA, Maroni A, Colombi A, eds. Occupational and environmental chemical hazards. Cellular and biochemical indices for monitoring toxicity. Chichester: Ellis Horwood, 1987:297-303.

26 Lauwerys R, Bernard A. Preclinical detection of nephrotoxicity: description of the tests and appraisal of their health significance . Toxicol Lett 1989;46:13-29.

27 Mutti A. Detection of renal diseases in humans: developing markers and methods. Toxicol Lett 1989;46:177-91.

28 Brogren C-H, Christensen JM, Rasmussen K. Occupational exposure to chlorinated organic solvents and its effect on the renal excretion of $\mathrm{N}$-acetyl- $\beta$-D-glucosaminidase. Arch Toxicol 1986;S9:460-4.

29 Meyer RB, Fischbein A, Rosenman K, Lerman Y, Drayer DE, Reidenberg MM. Increased urinary enzyme excretion in workers exposed to nephrotoxic chemicals. $\mathrm{Am}$ f Med 1984;76:989-98.

30 Dubach UC, Le Hir M, Gandhi R. Use of urinary enzymes as markers of nephrotoxicity. Toxicol Lett 1989;46:193-6.

31 Schardijn GHC, van Eps SLW. $\beta_{2}$-microglobulin: Its significance in the evaluation of renal function. Kidney Int 1987;32:635-41.

32 Lauwerys RR, Bernard A. Early detection of nephrotoxic effects of industrial chemicals: state of the art and future prospect. Am F Ind Med 1987;11:275-85.

33 Hotz P, Pilliod J, Bernard A, et al. Hydrocarbon exposure, hypertension and kidney function tests. Int Arch Occup Environ Health 1990;62:501-8.

34 Bernard A, Viau C, Ouled A, Lauwerys R. Competition between low and high molecular weight proteins for renal tubular uptake. Nephron 1987;45:115-8.

35 Van Sittert NJ, Veenstra GE, Dumas EP, Tordoir WF. Biological effect monitoring of occupational exposure to 1,3dichloropropene: effects on liver and renal function and on glutathione conjugation. $\mathrm{Br} \mathcal{F}$ Ind Med 1991;48:646-8.

36 Viau C, Bernard A, Lauwerys R, et al. A cross-sectional survey of kidney function in refinery employees. $\mathrm{Am} \mathrm{F}$ Ind $\mathrm{Med}$ $1987 ; 11: 177-87$.

Accepted 13 July 1992 